\title{
Analysing the Economic Resilience of D8 Countries by Using AHP and Topsis Approach
}

\author{
Haider Abbas* \\ Department of Economics, Ahlul Bayt International University- Tehran \\ Next to Tehran Qom's ETC, Khalij Fars Freeway, Tehran, Iran
}

\begin{abstract}
The research is financed by Ahlul Bayt International University, Tehran, Iran.
\section{Abstract}

Resilience is defined in different ways by different disciplines and different authors, but in general, resilience may be defined as the ability of a system and its component parts to anticipate, absorb, accommodate, or recover the effects of a hazardous event in a timely and efficient manner. The notion of 'resilience' has recently risen to prominence in several disciplines, and has also entered policy discourse. This paper determines the economic resilience of D-8 countries. AHP and TOPSIS approach have been used to evaluate the ranking of D-8 countries. The weight of different indicators has been derived by expert choice software. The results of the study show that Egypt tops the ranking among D-8 countries, followed by Iran, Nigeria, Pakistan, while Malaysia and Indonesia being at no 7 and 8 respectively due to macroeconomic indicators and the selected determinants of the economic resilience. Policymakers can play an active role in sustaining resilient economies by addressing resources and efforts in the right policy areas without waiting for crises. The paper also presents a tentative approach aimed at developing an index of economic resilience covering four aspects namely macroeconomic stability, microeconomic market efficiency, governance and social development.
\end{abstract}

Keywords: Economic resilience, , D-8 countries, AHP-TOPSIS

DOI: $10.7176 / \mathrm{JESD} / 12-21-01$

Publication date: November $30^{\text {th }} 2021$

\section{Introduction of Economic Resilience}

The notion of resilience has been used for a long time in the physical sciences, engineering, ecological sciences and psychology, but in the last few decades, it attracted the attention of regional economists and geographers (Martin 2012:P 2). More resilient countries are likely to less period of consequence and recover quicker then less resilient countries. Hence, different losses arise during the recession and positive change outcome helpful in order to direct engineering resilience (Paolo Di Caro: P3). Most of the dictionaries define the resilience term as the ability to recover quickly from shock, but in economic literature this has been used in three senses, i.e., shock counteraction (ability to recover quickly), shock absorption (the ability of an economy to withstand against shock) and the third is termed as the ability of an economy to avoid shocks (Briguglio, 2006:P 7). Hence, Economic resilience is a term that was coined by the economists after the great economic depression of 2008. Since then, numerous determinants have been used by different economists to calculate the resistance of any economy against these shocks. However, among them, the determinants used by Briguglio are broadly appreciated. In the contemporary global economic situation, countries are subjected to a wide variety of economic shocks, including, financial crises, foreign debt crises, commodity price fluctuations and natural disasters. They may increase the risk and uncertainty of the households. Investors, customers and governments. In the case of such vulnerabilities, economy should be resilient to adverse shocks, because they could derail the sustainable growth and developments of the country. That's why theses shocks are the main concern of the policy makers to identify the crucial factors of the country's resilience to adverse shocks. They may be defined the capacity and potential of the country to cope with such shocks and probability to reduce these vulnerabilities (Rohn, 2015:P 5).

The D-8 Organization for Economic Cooperation, also known as Developing-8, is an organization for development co-operation among the following countries: Bangladesh, Egypt, Nigeria, Indonesia, Iran, Malaysia, Pakistan, and Turkey. The objectives of D-8 Organization for Economic Cooperation are to improve member states' position in the global economy, diversify and create new opportunities in trade relations, enhance participation in decision-making at international level, and improve standards of living. D-8 is a global arrangement rather than a regional one, as the composition of its members reflects. Organization for Economic Cooperation (D-8) is a forum with no adverse impact on bilateral and multilateral commitments of the member countries, emanating from their membership to other international or regional organizations.

The combined population of the eight countries is about 1 billion or $60 \%$ of all Muslims, or close to $13 \%$ of the world's population and covering an area of 7.6 million square kilometers, 5\% of world land area. In 2006, trade between the D-8 member states stood at $\$ 35$ billion, and it was around $\$ 68$ billion in 2010. Transactions between the 8 developing countries account for 3.3 percent of world trade.

As stated by the D-8 Facts and Figures Publication: "The objectives of D- 8 are to improve developing countries' positions in the world economy, diversify and create new opportunities in trade relations, enhance 
participation in decision-making at the international level, and provide better standards of living."

This research shall be studying the Economic Resilience of these countries on the basis of determinants of Economic Resilience.

Economic resilience is new buzz word in the economic literature that is attracting the economists. Because world is objectively being observed to adverse shocks, uncertainties and vulnerabilities. In this line, Briguglio worked about vulnerabilities of the economies who are mainly more vulnerable to adverse shocks. He developed the new framework and suggested that, how could we mitigate to exogenous shocks. That study and his work is broadly appreciated by the world leaders.

This study shall make use of the key determinants of economic resilience in the context of D8 countries. For the assessment of the economic resilience and ranking AHP-TOPSIS shall be deployed. This study shall help policy makers and government authorities of D8 countries to focuses some vulnerable points of the economy such as external debt, imports, investment in social sectors, diversification of exports etc. that are sensitive to external shocks, helping them to become more resilient.

\section{Discussion \\ Background of the Study}

After the Economic Recession of 2008 economists started focusing on how could risk of vulnerabilities be minimized against the undesired disturbances. They coined up a new term known as Economic Resilience which measured the countries' vulnerability to economic shocks. The FM global resilience index, defines the resilience as the combination of the vulnerability of a country to supply chain disturbance and the efficiency of the country to recover from such hurdles. The index explains twelve key components of resilience, including political risk, natural hazard risk quality, productivity, control of corruption, oil intensity, quality of infrastructure, urbanization rate and planning to risk management. These components are marginalized into three broad factors like, economic, risk quality and supply chain. In this method index is constructed and combined for 130 countries and territories. In 2016 Switzerland ranked first among the countries due to its efficient infrastructure, prime location, and quality for suppliers, economic productivity and resilience to oil shocks.

The world economic forum global risk report explored the qualitative and quantitate indicators to access the resilience of the national economy to adverse global shocks. It had been observed by main systems (economic, environmental, governance, infrastructure and society) of the economy by the five crucial component robustness, redundancy, resourcefulness, response and recovery. The smaller states of the world are considered highly vulnerable to having a high GDP per capita due to highly dependent on openness of international trade, strategic imports and concentration on exports to lack of their domestic market efficiency (Briguglio, 2009).

Briguglio (2004), divided the countries in four major scenarios termed as "best case", "self-made" "prodigal son" and worst case. The countries nominated as self-made are those which refer to the highest degree and inherent economic vulnerability, but due to adoption of suitable polices resist the shocks. The countries have self-made ability to build the economic resilience to exogenous shocks. The prodigal son countries those have a low degree of inherent vulnerability like a son who is born in the rich family. The worst countries scenarios lead to a high degree of inherent economic vulnerability, but adoption of economic resilience enable them to minimize the effects of shocks. Brguglio (2008), for the construction of resilience index has defined the four major areas, which were further divided into sub-indicators. Macroeconomic stability, microeconomic market efficiency, good governance and social development are essential components of the economic resilience. These components have ability to absorb the effects of adverse shocks. Microeconomics market efficiency depends on the economic freedom and choices of the consumer for construction index, he used the economic freedom world index, which has published by the Fraser institute yearly to define the ranking of countries for economic freedom, it also has been constructed by its sub-indicators like the size of government, sound money, system of property rights and freedom of international trade.

Aqeli et al. (2016) conducted studies to determine Iran's position among 21 countries (ECO members, Persian Gulf countries and Western neighbors and Russia) using the nine dimensions of resistance economics and corresponding international indicators. As a result, Iran is ranked 11th among the 21 selected countries with an average weight of 33.3 .

Rajabian et al. (2017) conducted a study to calculate the resilience of Iran's economy during the period 13971395 using Burman et al.'s indicators. The results of this study have found that the resilience of Iran's economy in 2001 was the highest and in 2009 was the lowest, and after 1392, the trend has increased relatively.

Sadegh Bakhtiari, Farzam Sajjadieh, (2018) defined Economic resilience as the capacity of an economy to resist shocks, to withstand the effects of a shock and to avoid the shocks altogether. The paper tries to follow the UNDP procedure in presenting Human Development Index. Thus, the same procedure will be followed to provide an Economic Resilience Index (ERI) They used data for 12 developing countries (Iran, Albania, Algeria, Azerbaijan, Kazakhstan, Malaysia, Tunisia, Egypt, Indonesia, Kyrgyzstan, Oman and Jordan) from the period 2005 to 2014. The countries were ranked based on the average of calculated ERI. The first rank was Kazakhstan, 
and the last one was Algeria; Iran was at the 8th place. In case of Iran, the paper argued that during this period, Iran confronted with several major economic and political sanctions from various international players, such as the United States, European Union and other unilateral sanctions in many cases even beyond the UN security council resolutions; those have serious effects on all aspects of Iran's economy.

Samani (2018), investigated his research project on" the impact of political stability on economic resilience" by vaulting that terrorism is the main factor that affects the political stability of the country from very recent years. His well-thought-out political stability is a more crucial factor of economic resilience that directly affects economic resilience. Hence, he divided the countries into developing and developed country group with data panel data spanning from 1996-2014 by using a simple regression model for panel data. He has also compared the important two factors, political stability and economic resilience in the capitalistic system and the Islamic economic system. The findings of the research conclude that political stability, control of corruption, political openness, rent to natural resources and economic openness has a positive, substantial association to the economic resilience of selected countries within a selected time period, while social openness has not significant affiliation with economic resilience. Granger causality test also confirmed that political stability, control of corruption, economic openness, and social openness are important factors of economic resilience, however, political openness has not eloquent causality to economic resilience which suggested by the result of this study. This study, attempts to find the economic resilience index among D-8 countries. It shall make use of the AHP -TOPSIS approach and the countries thereupon shall be ranked on the basis of the determinants of the economic resilience.

\section{Research Methodology}

The main topic of this research is to study of the performance of resistance economy in D-8 countries in the year 2017. The combined population of the eight countries is about 1 billion or $60 \%$ of all Muslims, or close to $13 \%$ of the world's population and covering an area of 7.6 million square kilometers, $5 \%$ of world land area. In 2006, trade between the D-8 member states stood at $\$ 35$ billion, and it was around $\$ 68$ billion in 2010. Transactions between the 8 developing countries account for 3.3 percent of world trade. On the ranking of Annual inward and outward flows of Foreign direct investment for the year 2017, Indonesia ranked on the top with $32.78 \%$, followed by Turkey (18.29\%), Malaysia (14.9\%), Egypt (11.8\%), Iran (8\%), Nigeria (5.58\%) and Pakistan (5.15\%). Bangladesh ranked last with $3.5 \%$ of the total annual inflow and outflow of foreign direct investment among the D-8 countries. (UNCTAD)

This research has been done in a library-documentary method based on analytical descriptive method. For calculating the economic resilience index of D-8 countries, five different determinants have been accessed. These are; Macroeconomic stability, macroeconomic market efficiency, social development, good governance and export independence. These shall be calculated by proxy variables. For calculating of macroeconomic stability, the country's fiscal deficit ratio to GDP, misery index, external debt ratio to GDP, government size and government expenditures have been used. Data of from Fraser Institute has been used as a proxy for determining macroeconomic market efficiency. To calculate social development, HDI indicators have been used. To calculate exports independence, exports ratio to GDP, export concentration index and exports diversification index have been used. To calculate good governance indicator from WGI have been used that are; voice and accountability, rule of law, government effectiveness, regulatory, control of corruption and legal system and property rights.

The data for above mentioned determinants in this research is taken from the WDI, WGI and HDI indicators as well as World Economic Freedom Report from websites of World Bank, OECD and UNCDTED.

In the next step, mentioned components are weighed using the AHP method and then the TOPSIS method. The countries are then ranked on the basis of the outcome.

\section{Analytic Hierarchy Approach: (AHP)}

This approach involves a series of steps that are listed below: -

Step 1: The first step is to define the qualitative and quantitative criteria and sub-criteria, develop a hierarchical structure with an aim at the top level, criteria at the second level and alternatives at the third level.

Step 2: Relative importance of different attributes/criteria, using a questionnaire, are assigned as underlined by specific economists keeping in mind the aim. The Saaty's comparison scale is used, as shown in Table I. Equations from 1 to 9 are derived from Saaty's AHP calculation.

$$
C_{i j}=\left[\begin{array}{cccccc}
C_{11} & C_{11} & \ldots & \ldots & \ldots & C_{1 n} \\
C_{21} & C_{22} & \ldots & \ldots & \ldots & C_{2 n} \\
: & : & : & : & : & : \\
: & : & : & : & : & : \\
: & : & : & : & : & : \\
C_{n 1} & C_{n 2} & \ldots & \ldots & \ldots & C_{n n}
\end{array}\right]
$$


Where $n$ is the criteria count, and $C_{j i}=1 / C_{i j}$, where $i$ and $j$ is 1 for $n$.

Table 1: Comparison, Value Scale

\begin{tabular}{|l|l|}
\hline$\underline{\text { Scale }}$ & $\underline{\text { Degree of Preference }}$ \\
\hline 1 & Equal Importance \\
\hline 3 & Moderate Importance \\
\hline 5 & Strong Importance \\
\hline 7 & Very, very Strong Importance \\
\hline 9 & Extreme Importance \\
\hline $2,4,6,8$ & Intermediate Importance \\
$1 / 3,1 / 7,1 / 9$ & Values of Inverse Comparison \\
\hline
\end{tabular}

Step 3: In the third step we create the normalized pairwise matrix ' $X$ ' by dividing each element in the matrix by sum total of its column:

$$
X_{i j}=\frac{C_{i j}}{\sum_{j=I}^{n} C_{i j}}
$$

Where, $i$ and $j$ is 1 for $n$

$$
X_{i j}=\left[\begin{array}{cccccc}
X_{11} & X_{11} & \ldots & \ldots & \ldots & X_{1 n} \\
X_{21} & X_{22} & \ldots & \ldots & \ldots & X_{2 n} \\
: & : & : & : & : & : \\
: & : & : & : & : & : \\
: & : & : & : & : & : \\
X_{n 1} & X_{n 2} & \ldots & \ldots & \ldots & X_{n n}
\end{array}\right]
$$

We can use this $\mathrm{X}$ matrix shown above to get the vector weights matrix $\mathrm{W}$ as:-

$$
W_{i}=\frac{\sum_{j=I}^{n} X_{i j}}{\mathrm{n}}
$$

where we get weight matrix

$$
W=\left[\begin{array}{c}
W_{1} \\
W_{1} \\
: \\
: \\
W_{n}
\end{array}\right]
$$

Where, $i$ and $j$ is 1 for $n$

Step 4: In the fourth step we multiply each column of the pairwise comparison matrix with its corresponding weight. The new matrix is obtained as:

$$
D_{i j}=\left[\begin{array}{cccccc}
C_{11} & C_{11} & \ldots & \ldots & \ldots & C_{1 n} \\
C_{21} & C_{22} & \ldots & \ldots & \ldots & C_{2 n} \\
: & : & : & : & : & : \\
: & : & : & : & : & : \\
: & : & : & : & : & : \\
C_{n 1} & C_{n 2} & \ldots & \ldots & \ldots & C_{n n}
\end{array}\right] \times\left[\begin{array}{c}
W_{1} \\
W_{2} \\
: \\
: \\
: \\
W_{n}
\end{array}\right]=\left[\begin{array}{c}
D_{1} \\
D_{2} \\
: \\
: \\
: \\
D_{n}
\end{array}\right]
$$

Where, $i$ and $j$ is 1 to $n$.

Step 5: In the fifth step we divide the sum of rows with the corresponding weight 


$$
E_{i}=\frac{D i}{w_{i}}
$$

Where, $i$ is 1 to $n$. Now, we can get the $\lambda$ value by

$$
\lambda_{\max }=\frac{\sum_{j=I}^{n} E_{i}}{\mathrm{n}}
$$

Where $i$ is 1 to $n$.

Step 6: The consistency index is calculated using the following formula

$$
\text { Consistency Index }=\frac{\lambda_{\max }-n}{\mathrm{n}-1}
$$

Step 7: In this step we calculate a Consistency Ratio (CR). Here, we try to find-out how consistent the judgments have been relative to large samples of purely random judgments. If $\mathrm{CR}$ is lower than 0.1 or equal to 0.1 , the calculations of the criteria are consistent otherwise the judgments are unreliable. The consistency ratio is calculated as $\mathrm{CR}=\mathrm{CI} / \mathrm{RI}$, where $\mathrm{RI}$ is a random index as given in table II.

Table II: Random Index Value Scale

\begin{tabular}{|c|c|c|c|c|c|c|c|c|c|c|}
\hline \hline $\mathrm{N}$ & 1 & 2 & 3 & 4 & 5 & 6 & 7 & 8 & 9 & 10 \\
\hline $\mathrm{RI}$ & 0 & 0 & 0.58 & 0.9 & 1.12 & 1.24 & 1.32 & 1.41 & 1.46 & 1.49 \\
\hline
\end{tabular}

In this research, the inconsistency ratio is automatically generated by using the expert choice, i.e., 0.06 which is less than 0.1. Thus, the weights given in Table III, can be used for TOPSIS calculations.

Step 8:

$$
A_{i j}=\left[\begin{array}{cccccc}
A_{11} & A_{11} & \ldots & \ldots & \ldots & A_{1 n} \\
A_{21} & A_{22} & \ldots & \ldots & \ldots & A_{2 n} \\
: & : & : & : & : & : \\
: & : & : & : & : & : \\
: & : & : & : & : & : \\
A_{m 1} & A_{m 2} & \ldots & \ldots & \ldots & A_{m n}
\end{array}\right]
$$

Where $m$ represents the number of the selected countries which is 8 in our case, and $n$ is the criteria counts which is 11 in our specified model.

\section{TOPSIS Approach}

The Topsis method was first introduced by Huang Yun in 1981, and is one of the best multi criteria decision making methods. In the mentioned method, the $m$ option is evaluated by $\mathrm{n}$ index (Fallahi et al., 2017, p. 106). Based on this method, the selection of the option is done in such a way that the answer has the least distance with the positive ideal and the least distance with the negative ideal (Archaeological and Martial, 2014, p. 67). Based on this method, the selection of the option is done in such a way that it has the least distance with the positive answer and the least distance with the negative ideal (Archaeological and Martial, 2014, p. 67).

We shall use the TOPSIS approach to determine the final ranking of countries. It involves the following steps Step 9: To perform TOPSIS calculations, first we normalize the matrix $A_{\mathrm{ij} .}$. Then a new matrix is obtained by the following formula:

$$
N_{i j}=\frac{A_{i j}}{\sqrt{\sum_{j=I}^{m} A_{i j}}}
$$

Where $m$ represents number of countries. The normalized matrix is shown in appendix table III

Step 10: In this step, we multiply each entry with its corresponding weight to get new matrix which is a weighted normalized matrix $\mathrm{K}_{\mathrm{ij}}$, as shown in table IV. 


$$
K_{i j}=\left[\begin{array}{cccccc}
N_{11} & N_{11} & \ldots & \ldots & \ldots & N_{1 n} \\
N_{21} & N_{22} & \ldots & \ldots & \ldots & N_{2 n} \\
: & : & : & : & : & : \\
: & : & : & : & : & : \\
: & : & : & : & : & : \\
N_{m 1} & N_{m 2} & \ldots & \ldots & \ldots & N_{m n}
\end{array}\right] \times\left[\begin{array}{c}
W_{1} \\
W_{2} \\
: \\
: \\
: \\
W_{n}
\end{array}\right]
$$

Where $m$ is the number of countries and $\mathrm{n}$ is the criteria count. Also, $i$ and $j$ is 1 to $n$ Step 11: In this step the positive ideal solution can be found at:

$$
A_{j}^{+}=\operatorname{Max}\left(K_{i j}\right)
$$

While, negative ideal solution found at:

$$
A_{j}^{+}=\operatorname{Max}\left(K_{i j}\right)
$$

Where $i 1$ to $m$ that is number selected countries and $j 1$ to $n$ that is criteria count. In this step, we find ideal best and ideal worst solution. It is pertinent to note here, the minimum value of misery index, external debt to GDP and tax burden represents the best ideal solution because, normally, lower value of external debt and misery index favor country's macroeconomic stability. Same is the case in tax burden. The ideal best and worst value is shown in table $\mathrm{V}$.

Step 12: In this step we calculate the Euclidean distance from the ideal best and the ideal worst values using the following formula:

$$
S_{i}^{+}=\sqrt{\sum_{j=l}^{n}\left(K_{i j}-A_{j}^{+}\right)^{2}} \quad S_{i}^{-}=\sqrt{\sum_{j=1}^{n}\left(K_{i j}-A_{j}^{-}\right)^{2}}
$$

Where $i$ is 1 to $m$ that is the number of selected countries while $j$ is 1 to $n$ which is criteria count Step 13: In this step we shall calculate the final score using:

$$
P_{i=}=\frac{S_{i}^{-}}{S_{i}^{-}+S_{i}^{+}}
$$

Where $i 1$ to $m$ which is the number of selected countries. In addition, countries with higher performance score would be ranked higher. In our model Egypt ranked first with Iran taking second place and Indonesia ranked last as shown in the figure I below.

Figure I

Ranking of countries. Source: AHP and TOPSIS Approach

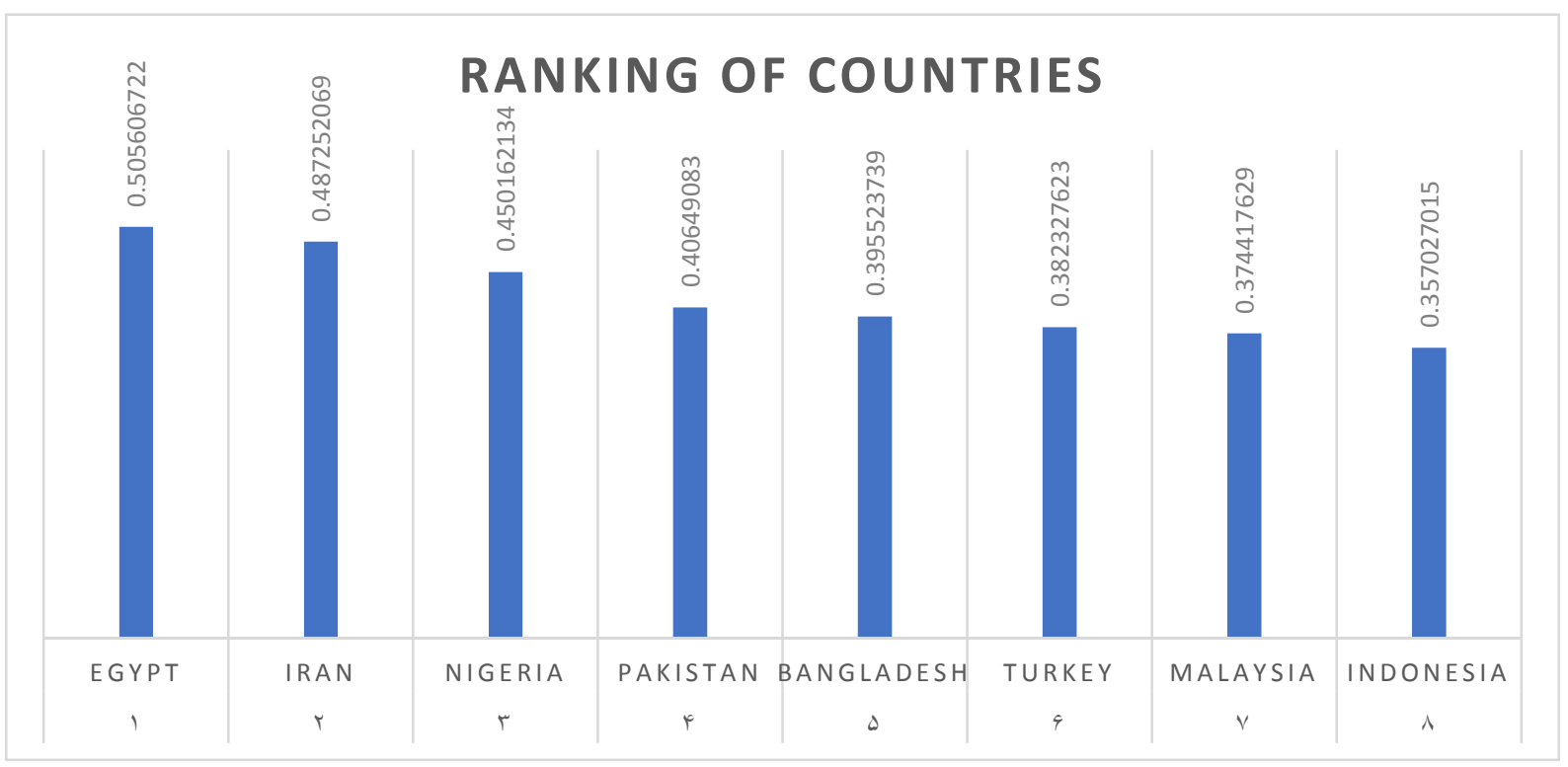




\section{Conclusion}

The study shows that Egypt tops the ranking among D-8 countries followed by Iran, Nigeria, Pakistan and so on. While Turkey, Malaysia and Indonesia are at the bottom 6, 7, and 8 respectively. Egypt scores 0.5056, Iran 0.4872, Nigeria 0.4501, Pakistan 0.4068, Bangladesh 0.3955, turkey 0.3823, Malaysia 0.3744 and Indonesia scores lowest 0.3570 through AHP and TOPSIS approach.

The most weighted indicators were HDI, Misery Index and fiscal deficit \% of GDP due their importance in the context of economic resilience. Egypt and Iran were amongst the countries having high HDI and Misery Indexes, resulting in their top ranking. It can be concluded from their scores that they are not dependent on the economy of the world. They are economic resilient. Any shock in the external world may not have much impact on their economies. Malaysia and Indonesia despite having a better HDI than other countries did not have a good fiscal deficit percentage and Misery Index. Hence, they ranked low on the scores and were found out to be less resilient. We can conclude that Malaysia and Indonesia are good developing countries but their economy is very much dependent on the external world. Turkey being located in between Asia and Europe is very much dependent on the world economy and as the stats show, since it has very low export concentration is ranked pretty low. Pakistan and Bangladesh having low HDI but their higher export diversification earned them fourth and fifth place. Nigeria is ahead of them on third place because it has a better HDI.

In the year 2017, due to low global commodity prices a range of supply side measures and tight stance monetary policy that resulted in a sharp decline in CPI from an average 9\% in 2011-13 to around 4\% during 201718. The account deficit was narrowed from a high $4.8 \%$ of GDP in 2012-13 with an average around $1.3 \%$ of GDP during 2013-14 and 2016-17.

Iranian economy although having severe sanctions imposed by USA showed the good situation in that year upon the considerations of the selected determinants. Mainly fiscal deficit has reduced to around 1.3 percent in that year. The country has been in a better position among D-8 countries due to good social development, less poverty indexes, large size of exports and low external debt ratio to GDP comparisons. They Iranian economy due to the sanctions imposed by US has therefore been successful in developing a resilient economy that is dependent on itself and not on the rest of the world and therefore is not volatile to external shocks.

\section{Appendixes}

\begin{tabular}{|l|l|l|l|l|l|l|l|l|l|l|l|}
\hline \multicolumn{1}{|c|}{ Appendix A: Normalized Matrix } \\
\hline Countries & $\begin{array}{l}\text { Fiscal } \\
\text { difficit \% of } \\
\text { GDP }\end{array}$ & Misery Index & $\begin{array}{l}\text { External } \\
\text { debt } \% \text { of } \\
\text { GDP }\end{array}$ & $\begin{array}{l}\text { Government } \\
\text { size }\end{array}$ & $\begin{array}{l}\text { Government } \\
\text { Expenditure }\end{array}$ & Regulation & HDI & $\begin{array}{l}\text { Export \% of } \\
\text { GDP }\end{array}$ & $\begin{array}{l}\text { Export } \\
\text { concentration } \\
\text { index }\end{array}$ & $\begin{array}{l}\text { Export } \\
\text { diversification } \\
\text { index }\end{array}$ & $\begin{array}{l}\text { WGI } \\
\text { Iran }\end{array}$ \\
\hline Pakistan & 0.043153005 & 0.393371985 & 0.971453314 & 0.274025438 & 0.446304699 & 0.298226898 & 0.482056129 & 0.21509264 & 0.464557185 & 0.37460951 & 0.190756813 \\
\hline Bangaldesh & 0.052124288 & 0.1605937 & 0.172901647 & 0.409030645 & 0.199262451 & 0.355209538 & 0.296537558 & 0.3567997 & 0.384344815 & 0.4658658 & 0.242279464 \\
\hline Egypt & 0.990361476 & 0.671954075 & 0.061024111 & 0.243912752 & 0.335399312 & 0.254557959 & 0.338900067 & 0.33915338 & 0.13461174 & 0.302122392 & 0.25250484 \\
\hline Turkey & 0.042075899 & 0.391165793 & 0.036790331 & 0.33123954 & 0.481447504 & 0.321126464 & 0.391974933 & 0.21655458 & 0.075459515 & 0.228110396 & 0.403446281 \\
\hline Nigeria & 0.048099149 & 0.401374975 & 0.10938284 & 0.431113281 & 0.146337379 & 0.412724725 & 0.259531229 & 0.4073077 & 0.722097234 & 0.449591026 & 0.207964643 \\
\hline Malaysia & 0.050406488 & 0.129677935 & 0.030541841 & 0.323209491 & 0.404769614 & 0.461719144 & 0.390514157 & 0.07659132 & 0.182360337 & 0.230289988 & 0.599291942 \\
\hline Indonesia & 0.046654645 & 0.142369258 & 0.056795239 & 0.417060694 & 0.301964118 & 0.3445585577 & 0.34279547 & 0.26573856 & 0.134783415 & 0.291969091 & 0.464610233 \\
\hline
\end{tabular}

Appendix B: Weighted Matrix

\begin{tabular}{|c|l|l|l|l|l|l|l|l|l|l|}
\hline $\begin{array}{l}\text { Fiscal } \\
\text { difficit \% } \\
\text { of GDP }\end{array}$ & $\begin{array}{l}\text { Misery } \\
\text { Index }\end{array}$ & $\begin{array}{l}\text { External } \\
\text { debt \% } \\
\text { of GDP }\end{array}$ & $\begin{array}{l}\text { Government } \\
\text { size }\end{array}$ & $\begin{array}{l}\text { Government } \\
\text { Expenditure }\end{array}$ & Regulation & HDI & $\begin{array}{l}\text { Export \% } \\
\text { of GDP }\end{array}$ & $\begin{array}{l}\text { Export } \\
\text { concentration } \\
\text { index }\end{array}$ & $\begin{array}{l}\text { Export } \\
\text { diversification } \\
\text { index }\end{array}$ & \begin{tabular}{l} 
WGI \\
\hline 0.10
\end{tabular} \\
\hline & 0.11 & & & & & & & & & \\
\hline \\
\hline
\end{tabular}




\begin{tabular}{|c|c|c|c|c|c|c|c|c|c|c|c|}
\hline Countries & $\begin{array}{l}\begin{array}{l}\text { Fiscal } \\
\text { difficit \% of } \\
\text { GDP }\end{array} \\
\end{array}$ & Misery Index & $\begin{array}{l}\text { External } \\
\text { debt \% of } \\
\text { GDP }\end{array}$ & $\begin{array}{l}\text { Government } \\
\text { size }\end{array}$ & $\begin{array}{l}\text { Government } \\
\text { Expenditure }\end{array}$ & Regulation & HDI & $\begin{array}{l}\text { Export \% of } \\
\text { GDP }\end{array}$ & $\begin{array}{l}\begin{array}{l}\text { Export } \\
\text { concentration } \\
\text { index }\end{array} \\
\end{array}$ & $\begin{array}{l}\text { Export } \\
\text { diversification } \\
\text { index } \\
\end{array}$ & WGI \\
\hline Iran & 0.004315301 & 0.043270918 & 0.083544985 & 0.023292162 & 0.028563501 & 0.023261698 & 0.062667297 & 0.019143245 & 0.045526604 & 0.031841808 & 0.014306761 \\
\hline Pakistan & 0.007618165 & 0.014235524 & 0.006191343 & 0.029947066 & 0.023979665 & 0.026418643 & 0.035321567 & 0.057824353 & 0.019552154 & 0.033884305 & 0.018389858 \\
\hline Bangaldesh & 0.005212429 & 0.017665307 & 0.014869542 & 0.034767605 & 0.012752797 & 0.027706344 & 0.038549883 & 0.031755173 & 0.037665792 & 0.039598593 & 0.01817096 \\
\hline Egypt & 0.099036148 & 0.073914948 & 0.005248074 & 0.020732584 & 0.021465556 & 0.019855521 & 0.044057009 & 0.030184651 & 0.01319195 & 0.025680403 & 0.018937863 \\
\hline Turkey & 0.00420759 & 0.043028237 & 0.003163968 & 0.028155361 & 0.03081264 & 0.025047864 & 0.050956741 & 0.019273358 & 0.007395032 & 0.019389384 & 0.030258471 \\
\hline Nigeria & 0.004809915 & 0.044151247 & 0.009406924 & 0.036644629 & 0.009365592 & 0.032192529 & 0.03373906 & 0.036250385 & 0.070765529 & 0.038215237 & 0.015597348 \\
\hline Malaysia & 0.005040649 & 0.014264573 & 0.002626598 & 0.027472807 & 0.025905255 & 0.036014093 & 0.05076684 & 0.006816627 & 0.017871313 & 0.019574649 & 0.044946896 \\
\hline Indonesia & 0.004665464 & 0.015660618 & 0.004884391 & 0.035450159 & 0.019325704 & 0.026875569 & 0.044563411 & 0.023650732 & 0.013208775 & 0.024817373 & 0.034845767 \\
\hline
\end{tabular}

\begin{tabular}{|c|c|c|c|c|c|c|c|c|c|c|c|}
\hline $\mathrm{V}+$ & 0.099036148 & 0.0739 & 0.083544985 & 0.036645 & 0.03081264 & 0.036014093 & 0.062667297 & 0.057824 & 0.070765529 & 0.039598593 & 0.044946896 \\
\hline V- & 0.00420759 & 0.0142 & 0.002626598 & 0.020733 & 0.009365592 & 0.019855521 & 0.03373906 & 0.006817 & 0.007395032 & 0.019389384 & 0.014306761 \\
\hline
\end{tabular}

Appendix D: Euclidean Distance Performance Score

\begin{tabular}{|c|c|c|c|c|}
\hline Countries & $\mathrm{D}+$ & $\mathrm{D}-$ & $\mathrm{A}$ & Ranking \\
\hline Egypt & 0.413079 & 0.422448 & 0.505607 & 1 \\
\hline Iran & 0.422038 & 0.401053 & 0.487252 & 2 \\
\hline Nigeria & 0.447276 & 0.366193 & 0.450162 & 3 \\
\hline Pakistan & 0.466928 & 0.319796 & 0.406491 & 4 \\
\hline Bangladesh & 0.458015 & 0.299691 & 0.395524 & 5 \\
\hline Turkey & 0.469707 & 0.29074 & 0.382328 & 6 \\
\hline Malaysia & 0.478144 & 0.286174 & 0.374418 & 7 \\
\hline Indonesia & 0.473625 & 0.262992 & 0.357027 & 8 \\
\hline
\end{tabular}

\section{Acknowledgement}

At the very outset I would like to Thank God for providing me the capability to work. Secondly, I would like to thank my parents for providing me all the necessary support. I would also like to thank all my seniors and friends who helped in the completion of this article. I would also like to thank my teachers for all the knowledge provided to me by them. I would also like to thank my mentor Mr. Gaffari Fard for providing me the assistance in the completion of this article. Last but not the least I would like to thank my university for giving me the platform to showcase my talents and abilities.

\section{References:}

1. Martin, Ron. (2012). "Regional Economic Resilience, Hysteresis and Recessionary Shocks". Journal of Economic Geography. 12. 1-32. 10.1093/jeg/lbr01

2. Bakhtiari, S. \& Sajjadieh, F (2018) "Theoretical and Empirical Analysis of Economic Resilience Index". Iranian Journal of Economic Studies, 7(1) 2018, 41-53

3. Briguglio, L; Cordina, G; Forrugia, N. \& Vella, S (2008) "Economic vulnerability and Resilience: Concepts and Measurement"; Oxford Development studies, vol.37 Issue. 3.

4. Briguglio, Lino \& Cordina, Gordon \& Bugeja, Stephanie \& Farrugia, Nadia. (2006). Conceptualizing and measuring economic resilience.

5. Hermans, M \& Oliver, R (2017) "Economic resilience: The usefulness of early warning indicators in OECD countries"; OECD Journal: Economic Studies, vol. 2016, issue1.

6. Rajabian, MA \& Sabahi (ed.) (2017) "Strategies to increase the resilience of economy by emphasizing the future of Iran economy", Quarterly journal of Islamic economic studies N- 89

7. Fard, MG \& Hussain, M. (2019) "Evaluating the Economic Resilience of SAARC Countries By using AHPTOPSIS Approach"; Quarterly social \& religious research journal, vol. 2, No, 44.

8. Briguglio, L \& Cordina, G (2008) Economic Vulnerability and Resilience concepts and measurements research paper no, 2008/55, United Nations University, UNU-WIDER

9. Briguglio, L \& Eliawonsay (2004), Economic Vulnerability and Resilience of Small States Island and Small 
Institute and Common Wealth Secretariat.

10. Briguglio.L (2009) Prepared for the Conference "small states and state", Tallin, Estonia.

11. Sanchez, C; Oliver, R (2015), "Economic resilience:what role for policies:OECD” Economics Department Working paper no;1251,OECD ,Publishing Paris.

12. Economic Freedom/ fraserinstitute.org of the World, 2018. Annual Report.

13. Reza, F (2018). "Resilience to shocks of the Iranian insurance sector". Unpublished Master Thesis, Allama Tabatabi University Tehran, E.C.O College of insurance department of Actuarial Sciences

14. FM Global,( 2018).Resilience Index Methodology (pentland ANALYTICS)

15. Oxford Metrica,( 2016)," The 2016 FM Global Resilience Index", Annual Report.

16. Samani, HA (2018). "The impact of political stability on economic resilience." Unpublished Master Thesis, Yazid University Social Sciences Department

17. Paolo, DC \& Fratesi, U (2018) "Regional determinants of economic resilience." Ann Reg Sci (2018) 60:235240 